\title{
The Portrayal of Male Fools in Jane Austen Pride and Prejudice
}

\author{
Ali Albashir Mohammed Al-Haj ${ }^{1}$ \\ ${ }^{1}$ Faculty of Arts \& Humanities, Department of English \& literature, Jazan University, Jazan, Kingdom of Saudi \\ Arabia \\ Correspondence: Ali Albashir Mohammed Al-Haj, Faculty of Arts \& Humanities, Department of English \& \\ literature, Jazan University, P. O. Box 114, Jazan, Kingdom of Saudi Arabia. E-mail: dr_abomathani@yahoo.com
}

\author{
Received: March 10, 2014 Accepted: April 30, 2014 Online Published: May 27, 2014 \\ doi:10.5539/ells.v4n2p44 URL: http://dx.doi.org/10.5539/ells.v4n2p44
}

\begin{abstract}
The present study aims at studying the male fools in Jane Austen's Pride and Prejudice. Jane Austen's primary interest is people, not ideas, and her achievement lies in the meticulously exact presentation of human situations, the delineation of characters who are really living creatures, with faults and virtues mixed as they are in real life the writer's unique merits give a faithful representation of real life and this is what we meet in her masterpiece Pride and Prejudice. Also, humor touches and illuminates all her best characters.

Jane Austen is not a social reformer, she is only a keen social observer who reminds people of their shortcomings. For example in Pride and Prejudice. The writer uses fools and nerds as a medium for criticizing her own society in general and through the two males-Mr. Collins and Mr. Wickham. Also, she treats various themes: pride and prejudice, and human folly in particular.

Finally, the paper ends with the conclusion that, the characters of male fools in Pride and Prejudice are fixed characters, who do not change throughout. But in spite of that, they are worth attention, because they are interesting and are used for various themes.
\end{abstract}

Keywords: Jane Austen, Pride and Prejudice, fools, portrayal, characters, male, faults, virtues, humor

\section{Introduction}

Jane Austen was a born story-teller and reveled in it from early years. She wrote from sheer love of writing. Faithful observation, personal detachment, and a fine sense of ironic comedy are among Jane Austen's chief characteristics as a writer. Jane Austen was aware herself of the wide range of her novels, and took the line that it was better for her to do what she did well rather than try her hand at areas which might have less success. Her novels do indeed succeed because of their excellence, and because her characters are universally human, their particular social class being a thin veneer over features that are of universal significance. Manner matter greatly in Jane Austen's code of morality: "behavior must be and has to be controlled, even if feelings cannot be so regulated." (Stephen, 2001, p. 90)

Nevertheless, it is true that Jane Austen took very good care not to move out areas that she knew not just slightly, but through and through. It was only thus that her irony could attain due weight. If she had applied it to aspects of life she knew less well, it would have seemed flippant and brittle. In the mature novels the continuous ironic surface, which makes them very funny, nerveless provides a thoughtful fun, because it is so securely based. Austen's Pride and Prejudice opens with a typical example of her irony:

It is a truth universally acknowledged, that a single man in possession of a good fortune, must be in want of a wife. (Pride and Prejudice, p. 3)

The irony is double-edged, making fun both of enunciations of universal truths and of a husband-hunting mothers. Jane Austen's Pride and Prejudice is not laugher provoking, but it leaves a rippling sense of pleasure behind it. Her humor is quiet, delicate and ironical. She is not a satirist, for satire connotes moral purpose. Jane Austen never lashed our follies, she faintly arched her eyebrows and passed on.

Jane Austen's view of life is a totally realistic one. She has no sentimentality, no time for emotional excess. Though her subject is love and marriage, her novels never produce a warm glow, never for a moment aspire the poetic. She honors The Augustan virtues of moderation, dignity, disciplined emotion and common sense, and she used her ironic wit to deflect heartbreak. Nash (1999) has rightly pointed out that: 
Pride and Prejudice is a social comedy and humorous novel which reflects that Jane Austen was suspicious of romantic excesses. Her attitude was realistic, and life-like, and was without excessive or sentimentally emotional excess. (p. 65)

Whatever said about Pride and Prejudice-which is the author herself thought "too lighter and bright and sparkling"-won't be sufficient without adding what Jane Austen, the "character monger" said about it in her letter of fourth February, 1813 to Cassandra:

The work is rather too light and bright and sparkling, it wants to be stretched out here and there with a long chapter of sense, if it could had; if not, of solemn specious nonsense, about something unconnected with the story; an essay on writing, a critique on Walter Scot, or the history of Bonaparte, or anything that would form a contrast, and bring the reader with increased delight to the playfulness and epigrammatism of the general style. (Chapman, 1986, p. 134)

Newton (1990, p. 34) has argued that women novelists like Austen and Eliot have sometimes subverted masculine dominating by giving emphasis to female capability. According to him, this "power of ability or capability" can be defined as "achievement and competence, and by implication, as a form of self-definition or self-rule". In this sense, Austen is interested in presenting her female characters as powerful; by exploring the process by which they choose a direction for their lives. On her turn Virginia Woolf (1997) praises women writers like Jane Austen who were able to overcome the fear and to speak their own truth:

... What genius, what integrity it must have required in face of all that criticism, in the midst of that purely patriarchal society, to hold fast to the thing as they saw it without shrinking. (p. 6)

The special charm of Jane Austen's novels lies, not in any greater insight into character, but in the fine impartiality with which she individualizes and differentiates them. Jane Austen, also loving her kind, loved them with the joy of the scientist. She found them crowding about her tea parties, her church gatherings, her balls, and she reproduced them for us with an unemotional fidelity, sometimes as little cruel, but never unfair.

\section{Jane Austen's Contribution, Reputation and Writing Career}

\subsection{Jane Austen's Life: Family and Social Background}

Jane Austen was born on 16th December, 1775, in the village of Stevenson, near Basingstoke, in Hampshire. The Seventh of eight children of the Reverend George Austen and his wife Cassandra, she was educated mainly at home and never lived apart from her family. In fact, at every point almost Jane Austen presents the exact antithesis to other daughter of a country person destined later on to make the Yorkshire moors articulate.

She died on $18^{\text {th }}$ of July at Winchester, in the north aisle of the cathedral. At her death Jane Astern occupied no place in English literature. She was rated lower than many contemporaries, whose names, fifty years later, had been completely forgotten. On the other hand, she is today lodged among the lasting classics Kennedy (1990, p. 54).

As a young woman, she enjoyed dancing at local ball, walking in the Hampshire countryside and visiting friends. She was an avid reader. She read both the serious and the popular literature of the day. She was very familiar with eightieth-century novels, including the works of Richardson. Through her active social life, she met many wanted to marry her, but she remained single all her life. On one occasion, she did accept a proposal of marriage from the brother of one of her closet friends, but she changed her mind the following day. As Rickett (2003) opines:

Jane Austen was earner and equal, caring for many things but for nothing in an especial degree. Most things amused her; few things angered her. She greets those she dislikes with a slight contemptuous simple; she never rages at them. And this power of self-detachment, of eliminating from story those strong predictions that often sway an author's creations enabled her to be an artist pure and simple. (p. 264)

In the period when Jane Austen wrote, great changes were occurring in Europe. The French Revolution and the collapse of the "ancient regime" in France were followed by the Napoleonic wars. In England, too, this was a period of political and social unrest. Music, literature and painting were also undergoing change in the form of the great Romantic Revolution. There is hardly any mention of these events in Jane Austen novels. Her novels deal with the relationships between families and individuals in a rural setting. She herself said "Three or four families in a country village is the thong to work on" (as cited in Kennedy, 1990, p. 58). She confined her writing to the world she knew from first-hand experience. 


\subsection{Jane Austen's Contribution, Reputation and Writing Career}

The secret of Jane Austen's power lies in the complete mastery she has as an artist over her materials. Six novels alone stand to Jane Austen's credit: Pride and Prejudice (1813), Mansfield Park (1814), Emma (1816), Persuasion (1818), Northern Abbey (1818), another novel, Lady Susan, was never published, and the Watsons she left unfinished.

Many readers, even in the United Kingdom, have an impression that Jane Austen was an early Victorian, a contemporary of Bronte Sisters, This fault idea is due to two reasons. First reason is the way in which the motion pictures show the characters of the novels, Jane Eyre, Catherine Earnshaw, and Elizabeth Bennet, for example, are dressed in the same fashion that makes the audience think of them as contemporizes. The other reason is the standard of Jane's books themselves; the books look so completely removed in thought, sentiment, and atmosphere from all that readers associate with the eighteenth century. Richardson (1689-1761) and Fielding (1707-1754) are, for readers, the typical novelist of that age. There is a gulf between Jane's Elizabeth and Richardson's Pamela that cannot be bridged. The two girls resemble different worlds, although, the same reign witnessed the deaths of Richardson and Jane Austen (Kennedy, 1990, p. 8).

Jane Austen started writing in the early teens. Her earliest works included parodies of the literature of the day and were originally written for the amusement of her family. Most of the pieces are dedicated to her relatives or family friends. In the period between 1811 and 1817 she wrote her six major novels. Kennedy (1990) has rightly pointed out that:

The six novels which built Jane Austen's fame and success were written over period of twenty one years between 1796 and 1817, but they were all published close together between 1811 and 1818. Her work is a living example of perfection. She wrote because she loved to write and she always did her utmost best to perfect her work. She once said laughingly about some designing which she had made to amuse an infant nephew, "an artist cannot do anything slovenly." (p. 67)

Jane Austen's novels give the impression of ease, but they are in fact the results of careful thinking by the author who was constantly revising them. Irony, wit and clear, balanced, apparently simple language are all essential elements of her style. The vividness of the characters and the lively dialogue have made the novels excellent material for theatre and cinema adaptation. In fact, in recent years Jane Austen has enjoyed renewed popularity, thanks to hugely successful films and television series based on her novel.

Jane Austen is probably best remembered for her analysis of character and conduct. Her characters have strengths and weakness, they go through times of trials and they learn lessons. They are not driven by wild passions. The strong impulses and intensely emotional states they experience are regulated controlled and brought to order by private reflection.

When Jane Austen was mature enough to look at people around her with a critical eye, she must have noticed three things. Firstly, she noticed that the manners and the culture to which she had been used in her fathers' house were not universal. Secondly, much lower standards can be witnessed in large country houses, among powerful land owners. Thirdly, these great people were not aware of their shortcomings. They think of themselves as a superior, better bred than anybody else. In their opinions a man who has to work is to rank lower than one who has not be. Jane Austen portrayed and bore witness in her novels in general and in Pride and Prejudice in particular. (Omer, 2002, p. 13)

To conclude, Jane Austen's commitment to reason and common sense rather than great passion links her work to the eightieth-century tradition of classicism. There is little evidence in her work of the passionate Romantic themes of the turn of the century.

\section{The Portrayal of Male Fools in Prejudice and Prejudice}

\subsection{Themes of Pride and Prejudice}

Further evidence of Jane Austen's preoccupation with her immediate world may be found in the themes of Pride and Prejudice. The traditional values of the middle and upper classes such as property, decorum, money and marriage are her majors concerns in her novels in general and in Pride and Prejudice in particular. In Pride and Prejudice, for example, marriage provides the basis of the plot. It is not surprising that marriage was a major preoccupation. At that time, women of the middle and upper classes were, of necessity, totally dependent on their husbands or fathers. Jane Austen herself experienced the risk of being left unsupported. When her father dies, he left his widow and two daughters a very small annual income. Life would have been difficult for the three women had not the surviving sons contributed to their income. 


\subsection{The Story of the Novel}

The Benets have daughters and Mrs. Bennet's driving ambition is to see all of them married. Charles Bingley has come to live nearby with his friends Darcy. When Darcy realizes that Charles likes Jane Bennet, he does his best to separate them on the grounds that her family are socially inferior. He himself likes Elizabeth Bennet, but when he says so to her, she says she can nothing to do with someone who looks down on her family. She changes her mind about him, however, when she learns that he has helped another sister, Lydia, who has eloped with a military officer, and the story ends happily with a double wedding between Charles and Jane, and Elizabeth and Dacry.

\subsection{Pride and Prejudice and Idea of Fools}

Jane Austen's fools are not simpler than her wise characters; rather they are complex entities. Her wise characters have some dash of folly in them and her fools have something to love.

A fool in Jane Austen's novels is not of little significance or unworthy of attention. Actually, Jane Austen grafts a collection of ideas on fool to make him a theme for different variations. Mr. Collin with his fixed ideas is a good example of that. According to Laumber (1998):

Mr. Collin is the most amusing fools in Pride and Prejudice, despite of his humorless and pedantic nature. His marriage proposal to Elizabeth is so far away from the passion and genuine care usually present in these situations, that it provokes laugher. (p. 34)

The way Jane Austen portrayed the fools of Pride and Prejudice is contrary to Aristotelian maxim that "all things, even stones, fishes and fools, pursue their proper end" (Simpson, 1997, p. 13).

To conclude, the characters of fools in her master piece, Pride and Prejudice are fixed characters, who do not change throughout. But in spite of that, they are worth attention, because they are interesting and are used for various themes.

\subsection{Two Male Fools: Mr. Collin and Mr. Wickham}

Mr. Collins: Mr. Collins, as a typical fool, is oblivious to other people's feelings and reactions. He is narrow minded in his understating of the roles of people in society; for him,

personal feelings are irrelevant, only the ceremony counts; even the identity of the bride does not matter very much. (Laumber, 1998, p. 214).

Mr. Collins' portrait as a male fool is the outcome of his empty mind and heart and his fixed ideas.:

Mr. Collins was not a sensible man, and the deficiency of nature had been but little assisted by education or society; the greatest part of his life having been spent under the guidance of an illiterate and miserly father; and though he belonged to one of the universities, he had merely kept the necessary terms, without forming at it any useful acquaintance.

The subjection in which his father had brought him up had given him originally great humility of manner, but it was now a good deal counteracted by the self-conceit of a weak head, living in retirement, and the consequential feelings of early and unexpected prosperity. A fortunate chance had recommended him to Lady Catherine de Bourgh when the living of Hunsford was vacant; and the respect which he felt for her high rank and his veneration for her as his patroness, mingling with a very good opinion of himself, of his authority as a clergyman, and his rights as a rector, made him altogether a mixture of pride and obsequiousness, self-importance and humility. (Pride and Prejudice, p. 59)

Mr. Collins' role in Pride and Prejudice begins as unsuitable suitor for Elizabeth. He shows selfish reasons for marrying and in addition humiliates Elizabeth during his proposal. He is not sensible enough to realize her genuine refusal. The situation is comic and it reveals to what extent Collins is insensitive and foolish. He says:

I am, therefore, by no means discouraged by what you have just said, and shall hope to lead you to the alter ere long. (Pride and Prejudice, p. 105)

Mr. Collin is vey literal and predicable, taking out all emotion and genuineness from his reactions to the world around him:

Here, leading the way through every walk and cross walk, and scarcely allowing them an interval to utter the praises he asked for, every view was pointed out with a minuteness which left beauty entirely behind. He could number the fields in every direction, and could tell how many trees there were in the most distant clump. (Pride and Prejudice, p. 107). 
Mr. Collins' proposal is refused because Elizabeth thinks of him to be conceited, arrogant, narrow minded and silly. As Nash (1999) opines:

The woman who maries him cannot have a proper way of thinking, Actually, Mr. Collins carries his formality and affected humility to the point of ridiculousness He says he comes "prepared to admire" the Bennet girls, and his courtship of Elizabeth, ending in the proposed of marriage's all the more humorous because he is unaware of anyone's feelings but his own. Even Collins' own feelings are unstable-he turns from Jane to Elizabeth, to Charlotte in far too rapid succession. (p. 49)

Mr. Collins is foolish because his one-dimensional character does not allow him to see the shades of gray, so for him, the only reality is the practical one, where emotion is just a word, not a real feeling:

The idea of Mr. Collins, with all his solemn composure, being run away with by his feelings, made Elizabeth so near laughing that she could not use the short pause he allowed in any attempt to stop him farther, and he continued. (Pride and Prejudice, p. 78)

Mr. Collins exemplifies the trend that a fool is not simply foolish; he is also proud of his foolishness on exhibiting himself. His ideas and conduct prove that he is not refined or well-educated. His mentality is not at all changing or growing. As Muir (1990) opines:

Mr. Collins is a fool and somewhat of a caricature. He has no great effect on the action. He is an end, not a means and an end at the same time; he remains unchanged throughout the story. (p. 45)

Collins continues to be foolish, The most extraordinary thing about his character is his apparent ability to take his own insincere rhetoric seriously. He does not seem to be aware of his foolishness, a fact which can only be attributed to his fixed stupidity. (Omer, 2002)

Mr. Collins esteems himself worthy to be always occupying a place in the notice of the people with whom he associate and that it is always his duty to interpret his motives and explain his reasons. Although he is noticed for being pompous and proud, he simultaneously a sense of humility. He always speaks of himself and his belongs as humble. He represses his humility towards his patrons and towards anybody who is of a higher rank than him. In addition to his personal claims, he exploits being a rector in the Church of England and forces his wrong pieces of advice upon people. He is outwardly a Christian clergyman, but he is by nature a sycophant and social climber always without charity. (Wilson, 1999, p. 76).

To conclude, Jane Austen's portrayal of Mr. Collin is an exception. His conceit and obsequiousness are evident and they show his lack of sense of what is correct and proper.

Mr. Wickham: In Jane Austen earlier novels there is no systematic attempt to connect wickedness with a deficiency of moral understanding. Wickham, the villain of Pride and Prejudice, does not show that he lacks an understanding of what virtue is, but he is connected with wickedness for wickedness. He is graceful and handsome; he has a very pleasing address. A charmer, he is utterly unreliable, and has attempted to seduce Georgian Darcy and to marry Miss King, before seducing Lydia. He is supremely selfish, but is found out, and his marriage is not successful. According to Whately (2001):

Mr. Wickham is in many respects wicked, or at least many of his actions are wicked. In the beginning of the novel everybody falls for Wickham. One can argue whether or not his name is intended to function as a foreshadowing of the coming events and his true character. (p. 57)

Wickham's character and appearance can only be discussed together. Appearance, beauty, fine countenance, good figure, pleasing address are outward advantages which he exploits thoroughly well to deceive everybody (Omer, 2002, p.79):

His appearance was greatly in his favor, he had all best part of beauty, a fine countenance, a good figure, and very pleasing address. (Pride and Prejudice, p. 49)

Compared to the reader's first impression of Mr. Darcy, Mr. Wickham is quite the opposite. In addition to his physical appearance, which is greatly in his favor, his conduct is pleasing and he is altogether perceived as a charming man. According to Nash (I999),

Compared to Collins, Wickham is also selfish and he only cares about outward appearance. The important difference between him and Collins is that he breaks the "social code" and he is eventually exposed. (p. 50)

Wickham is a male chauvinist who drops Elizabeth for Mary King and at the same time expects her to accept him on his return, but that angers Elizabeth and plays her decode Wickham's obscure character. In spite of his 
manner towards women, it is obvious that Wickham has some kind of latent disrespect for women which he uses to reach his evil goals. How he uses Georgia for revenge and money and Lydia for immoral pleasure are good examples.

Wickham is a portraiture of the worthless man who does wrong professionally, though he doesn't lack moral awareness. Darcy's housekeeper calls him "wild" (Pride and Prejudice, p. 235) and he deserves it. He behaves like a wild animal who breaks the "social code" in an anti-social manner that reflects emotional irrationality. Like the other fool males discussed above, Wickham is a doomed fool male who is not reformed throughout. We notice no change in him for good and such is the nature of stereotypes.

To conclude, through the character of Wickham, Jane Austen is able to warn society, and particularly women, of the dangers of their vulnerable position in a patriarchal society, with emphasis on men's power, and their unfair social position. Also Wickham represents what men should pay attention to and how women could recognize imposters and be careful.

\section{Conclusion}

Jane Austen's fools are not more simple than her round characters. They are complex entities. As we find some folly in her wise characters, we may also find something to like in her fools Jane Austen is considered a Shakespearean genius (Omer, 2002, p. 87).

Mr. Collins is recognized as humorous, foolish, pompous, conceited and self-important, boring man who is concerned with outward show, a snob who is materialistic. He is an example of an unfit suitor who calculates marriage. He is shown to us as a man of superficial feelings who is attracted in turn to Jane, Elizabeth and Charlotte. He is at once humble and self-important; he is not well-educated and, though a clergyman, most worldly. Mr. Bennet's description, "absurd" (Pride and Prejudice, p. 78), is a good one.

Mr. Collin shows selfish reasons for marriage, which are also comic. Collins is also criticized as a worldly clergyman, who is always condescending and is without charity. He has a servile mentality which be noted in his humility towards his patrons and superiors. Collins is a fixed character, who takes no step towards rotundity.

It is of interest to explore Austen's famous lines in Pride and Prejudice:

It is a truth universally acknowledged, that a single man in possession of a good fortune, must be in want of a wife. (Pride and Prejudice, p. 3)

These lines are famous because they encapsulate Jane Austen's ironical style: the statement is the complete opposite of the truth. When it comes to Wickham the tables have turned; just as women are in a desperate position, needing to find a rich man, so too is Wickham, wanting to marry a woman with a big fortune. Wickham is a man who has chosen himself in a woman' position due to his vanity and want of money.

To conclude, Wickham, the villain of Pride and Prejudice, is a charming character, who has the ability to please people especially women. He is bad in every way. He is not exposed until after elopement. Omer (2002) has rightly pointed out that:

Wickham as an attractive rogue has consummated the art of people pleasing, especially women. When Elizabeth tells him to his face that she knows all he has done, he only responds by kissing her hand! His mislead are achieved through a style which is his own. He can lie, gamble and seduce easily with his true picture masked. (p. 82)

Wickham is ruled only by self-interest. His charm is a medium which gets him to what he desires.

\section{References}

Austen, J. (1983). Pride and Prejudice. London: Oxford Univ. Press.

Baker, J. E. (1989). The Re-Interpretation of Victorian Literature. London: Macmillan.

Chapman, R. W. (Ed.). (1986). Jane Austen's Selected Letters. London: Macmillan Press..

Kennedy, M. (1990). Jane Austen. London: Roberts Hale.

Laumber, S. (1998). Jane Austen: Pride and Prejudice. London: Macmillan.

Muir, E. (1990). Characters \& Action in the Dramatic Novels. In Critics on Jane Austen. London: Oxford Universtiy Press.

Nash, G. (1999). Jane Austen and Pride \& Prejudice. London: Longman.

Newton, J. (1990). Jane Austen. London: Longman. 
Omer, A. (2002). Fools and Nerds in Selected Work of Jane Austen (Unpublished master's thesis). Yemen University, Sanaa, Yemen.

Rickett, C. (2003). The Rise of the Novel. London: Oxford Univ. Press.

Simpson, R. (1997). Jane Austen's Fools. In Critics of Jane Austen. London: Longman.

Stephan, L. (2001). Understanding of Jane Austen's Novels. London: Longman.

Whately, R. (2001). Instruction with Amusement in Critics on Jane Austen. London: Longman.

Wilson, R. ( 1999). Pride and Prejudice by Jane Austen. London: Macmillan.

Woolf, V. (1997). Jane Austen and Idea of Nerds and Fools. London: Roberts Hale.

\section{Copyrights}

Copyright for this article is retained by the author(s), with first publication rights granted to the journal.

This is an open-access article distributed under the terms and conditions of the Creative Commons Attribution license (http://creativecommons.org/licenses/by/3.0/). 